\title{
AKTUALISASI MAKNA SYARÎ'AH DAN FIQH DALAM KONSEP HUKUM ISLAM
}

\author{
Bustami Saladin \\ (Calon D osen STA IN Pamekasan, JI. Raya Panglegur Km. 04 Pamekasan, email: \\ bustamisaladin@yahoo.co.id)
}

\begin{abstract}
A bstract:
Islamic law is in accordance with its dimension in a history, that makes the content of the study in its dimension al ways appears any system or method. That's why in Rasulullah saw era, Islamic law is based on Allah swt's revelation and Rasulullah's judgment, namely, Islamic law in Alquran and Sunnah perspectives. The purpose of dedaring Islamic law is applying and protecting the benefit for people. It is applied in Islamic law that concerns all aspects of human life that has three aspects: dharûriyah (primary), hajiyah (secondary), and tahnisiyah (complementary).
\end{abstract}

\section{Keywords:}

Figh, syarî'ah, hukum Islâm, ijtihâd, al-Qur'ân, dan al-Hadîts

\section{Pendahuluan}

Hukum Islâm diyakini oleh umat Islâm sebagai sumber hukum yang bersumber Dâri Allâh swt. Keyakinan ini berdasarkan kenyataan bahwa sumber hukum dalam Islam adalah al-Qur'ân dan Sunnah, Dalam setting sejarah proses terbentuknya hukum Islâm sudah berlangsung pada masa nabi Muhammad saw. hal ini disebabkan karena nabi mempunyai kewenangan dan otoritas penuh yang melekat pada dirinya, serta legitimasi-legitimasi untuk melakukan itu, sementara generasi generasi setelah nabi Muhammad saw. mengembangkan konstruksi dasar hukum yang telah dibangun sebelumnya. Hal ini dapat terlihat dari usaha (ijtihâd) para fuqaha pada setiap periode yang telah berhasil merumuskan fiqh berdasarkan metodologi ushul figh dengan modifikasi-modifikasi tertentu yang tidak terlepas dari al-Qur'ân dan Sunnah yang tentu saja modifikasi 
Bustami Saladin

seperti ini merupakan hasil bargaining position antara figh dengan dinamika konstruksi sosial, budaya dan nilai nilai dalam masyarakat. Istilah Hukum Islâm sering diidentikkan dengan syarî'ah, namun bila dilihat dari metodologinya mempunyai perbedaan yang signifikan. Syarî'ah adalah al-nushûs al-muqaddasah (nash-nash hukum atau norma-norma hukum yang tertulis) dalam wahyu Allâh dan alsunnah al-mutawâtirah yang sama sekali belum atau tidak tercampuri oleh daya nalar manusia sehingga ia tetap dan tidak bisa berubah dan tidak boleh dirubah karena ia sebagai wahyu Allâh. ${ }^{1}$

Adapun figh adalah pemahaman atau hasil pengembangan interpretasi nalar manusia (ijtihâd mujtahid) dari syarî'ah (al-Qur'ân dan al-Hadîts) sehingga ia bisa berubah dan berkembang sesuai dengan kapasitas daya nalar mujtahid dan sesuai dengan perkembangan zaman. Sedangkan Hukum Islâm meliputi norma-

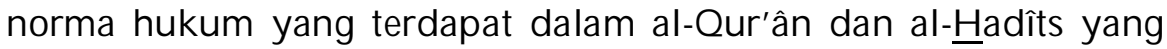
belum melibatkan daya nalar manusia dan norma-norma hukum yang dihasilkan oleh daya nalar manusia (fiqh ljtihâdî) sebagai hasil

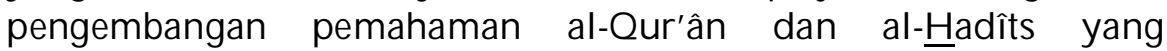
disesuaikan dengan tingkat kemampuan daya nalar manusia. ${ }^{2}$

Berangkat dari pemikiran tersebut, menjadi jelas perbedaan antara syarî’ah dengan fiqh. Syarî'ah adalah wahyu itu sendiri yang belum tercampuri oleh daya nalar manusia. Oleh sebab itu ia bersifat tsubut (tetap) dan tidak berubah. Sementara figh adalah hasil dari proses penalaran (pemahaman) mujtahid terhadap wahyu. karena itu ia bersifat tathawur (berkembang), bervariasi sesuai dengan tingkat kemampuan daya nalar mujtahid. Adapun hukum Islâm sebagai wahyu Allâh yang belum tercampuri daya nalar manusia adalah syarî'ah dan hukum Islâm sebagai pemahaman terhadap wahyu adalah fiqh. Dalam keterpaduan dua sifat ini (dimensi) inilah hukum Islâm bisa bertahan sepanjang masa dan berkembang, tidak kaku dalam berbagai situasi dan kondisi sosial

Hukum Islâm diformulasikan sebagai sekumpulan aturan keagamaan yang mengatur perilaku kehidupan kaum muslimin dalam segala aspeknya baik yang bersifat individual maupun

1 A bû Zahrah, U shûl al-Fiqh, (Kairo: Dâr al Fikr, 1377 H/ 1957 M.), hlm. 344

2 Harun Nasution, Islam Ditinjau D ari Berbagai A speknya, Jilid II, (Jakarta: Universitas Indonesia Press, 1979), hlm. 7. 
kolektif. Karekteristik yang serba mencakup inilah yang menempatkan posisi penting dalam pandangan umat Islâm. Bahkan sejak awalnya hukum Islâm telah dianggap sebagai pengetahuan par exellence, oleh sebab itulah para pengamat menilai adalah mustahil memahami Islâm tanpa memahami hukum Islâm. ${ }^{3}$

\section{Seputar Konsep Syarî'ah}

Secara etimologis syarî'ah berarti jalan tempat keluarnya air untuk minum, 4 atau jalan tenang untuk diikuti (the clear path to the folowwed).5 Dalam pemakaian yang bersifat religius kata ini mempunyai arti "jalan menuju yang baik", yaitu nilai-nilai agama yang diungkapkan secara fungsional dan dalam makna yang kongkrit yang bertujuan untuk mengarahkan kehidupan manusia. ${ }^{6}$

Kata syarî'ah bila dikaitkan dengan sumber air menunjukkan betapa vitalnya syarî'ah tersebut sebab sumber mata air menurut orang A rab adalah menunjukkan sesuatu yang luar biasa. Sementara itu dalam makna terminologis syarî'ah diartikan sebagai segala ketentuan yang disyariatkan bagi hamba-hamba-Nya baik menyangkut ibadah, akidah dan mu'âmalah. ${ }^{7} \mathrm{Al}$-Qur'ân menggunakan kata syarî'ah dalam pengertian dîn (agama) yang merupakan jalan lurus yang telah ditentukan oleh Allâh swt. untuk manusia dan merupakan ketentuan yang harus dilaksanakan sebagaimana firman Allâh swt. dalam surat al-Jâtsiyah: 18.

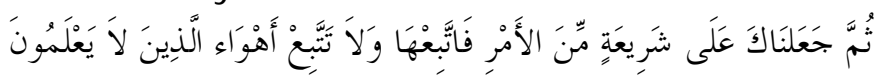

Artinya: Kemudian Kami jadikan kamu berada di atas suatu syariat (peraturan) dari urusan (agama itu), M aka ikutilah syariat itu

3 Joseph Schadht, An Intruduction in Islamic Law (London: Oxford at the darendon Press, 1971), hlm. 1

4 M uhammad Farûq Nabhân, al-M adkhal li al-T asy' rî' al-Islâmî, Jilid VIII, (Beirut:Dâr al-Shadir, t.th), hlm. 10

5 H.A.R Gibb and J.H Krames, Shorter Encyclopedia of Islam (London: Luzzac 1961), hlm. 102

6 Fazlurrahman, Islam, (Bandung: Pustaka, 1997), hlm. 140

7 Mannâ al-Qaththân, al-Tasyrî' wa al Fiqh fî al-Islâm (Beirut: Mu'assasah Risâlah, th), hlm. 14 
Bustami Saladin

dan janganlah kamu ikuti hawa nafsu orang-orang yang tidak mengetahui. 8

Ketika Nabi Muhammad SAW ditanya tentang syarî'ah beliau menjawab dengan shalat, zakat dan haji.9 Hal ini membuktikan bahwa terminologi syarî'ah pada masa Nabi digunakan untuk menyebut makna-makna yang esensial dari ajaran Islâm. Dengan demikian, syarî'ah meliputi segala ketentuan hukum yang ada dalam sunnah baik yang berkaitan dengan akidah, akhlak atau perbuatan manusia dalam bentuk ibadah dan muamalah.

Abû Hanîfah membedakan term syarî'ah dan dîn (agama), alasannya bahwa syarî'ah bersifat dinamis dalam pengertian bahwa syarî'ah mengalami perubahan sesuai dengan dimensi ruang dan waktu sementara din bersifat statis. Term din adalah ajaran-ajaran dasar dari agama yakni percaya kepada kekuasaan Allâh, nabi, kehidupan akhirat dan lain sebagainya sedangkan syarî'ah adalah kewajiban-kewajiban yang dilaksanakan oleh manusia. ${ }^{10}$ Bagi Imam A bû Hanîfah misi setiap Nabi adalah sama yaitu mengajarkan agama tauhid. Oleh sebab itulah setiap nabi selalu mengajarkan konsep monotheisme, tetapi pada saat yang sama juga mengajak kepada syarî'ah yang diajarkannya, tiap generasi periode nabi sebelum dan setelahnya terjadi perlengkapan syarî'ah, sehingga tentu saja tidak semua syarî'ah nabi-nabi terdahulu dibuang begitu saja sebab ada syarî'ah yang sifatnya modifkasi atau pembaharuan seperti ajaran haji yang merupakan warisan ajaran dari nabi Ibrahim, untuk itulah dalam yurisprudensi Islâm dikenal istilah konsep syar'u man Q oblanâ, dari sinilah wajar jika Gib memandang bahwa Imam Abu Hanifah telah menyamakan term figh dan syarî'ah. ${ }^{11}$

Dewasa ini terminologi syarî'ah mencakup semua aspek dari ajaran Islâm baik fiqh maupun kalam. Syarî'ah mempunyai ruang lingkup yang lebih luas daripada figh yang meliputi segala aspek kehidupan manusia sedangkan ruang lingkup figh lebih sempit dan

8 Departemen Agama RI., A I-Q ur'ân dan Terjemahannya, (Madinah: Majma' al-Mâlik Fahd li al-Thibâ'ah al-Mushhaf al-Syarîf, 1995).

9. A hmad Hasan, The Early Development of Islamic Jurisprudence, (Bandung: Pustaka, 1984), hIm. 7

10. H .A.R G ibb, M uhammadanism, (Jakarta: Baratha Karya Aksra,1983), hlm. 76

11.Ibid., hlm. 78 
menyangkut hal-hal yang pada umumnya dipahami sebagai aturanaturan hukum, syarî’ah senantiasa mengingatkan kita bahwa ia bersumber pada al-Qur'ân dan Hadîts, oleh sebab itulah arah dan tujuan syarî'ah telah ditentukan oleh Allâh dan Nabi-Nya. Sedangkan materi yang tercantum dari figh dalam perkembangannya disusun dan diangkat atas usaha dan ijtihâd manusia.

Dalam figh suatu pekerjaan bisa saja dikatakan sah atau haram, boleh atau tidak, sementara dalam syarî'ah terdapat tingkatan diperbolehkan atau tidaknya. Dengan demikian, figh merupakan terminologi tentang hukum sebagai salah satu ilmu, dalam figh bisa saja terjadi perbedaan interprestasi antara para mujtahid sementara syarî'ah lebih merupakan perintah ilahi yang harus diikuti. 12

Ada suatu perbedaan yang dapat ditarik dari kesimpulan tersebut bahwa syarî'ah mencakup hak-hak serta prinsip-prinsip dari ajaran Islâm sedangkan fiqh berkaitan dengan aturan-aturan hukum, syarî'ah juga mencakup persoalan-persoalan teologi dan etika sementara aksentuasi dan stressing figh lebih kepada persoalanpersoalan hukum ijtihadiyah dan perumusan hukum-hukumnya melalui metode istidlâl sehingga dalam perkembangan selanjutnya kata figh digunakan sebagai penunjuk hukum-hukum Islâm baik yang ditetapkan langsung oleh al-Qur'ân dan Sunnah maupun yang telah di interprestasikan oleh pemikiran manusia (ijtihâd). ${ }^{13}$ Selanjutnya istilah syarî'ah erat kaitannya dengan istilah tasyri' , syarî'ah ditujukan kepada materi hukum sedangkan tasyri' merupakan penetapan materi dari hukum syarî'ah tersebut, pengetahuan tentang tasyri' berarti pengetahuan tentang cara, proses, dasar dan tujuan Allâh swt. menetapkan hukum-hukum tersebut. ${ }^{14}$

\section{Seputar Konsep Fiqh}

Jika disimak hukum Islâm seirama dengan dimensinya dalam sejarah, maka isi pengkajian dalam setiap dimensinya mutlak menampakkan berbagai sistem atau metode. Oleh sebab itu, pada zaman Rasûlullâh saw. hukum Islâm secara bersahaja dapat diperoleh

12 Hasan, TheE arly D evelopment, hlm. 8-9

13 Fathurrahman Djamil Filsafat H ukum Islam (Jakarta: Logos,1999), hlm. 8

14 Amir Syarifuddin, Pengertian dan Sumber H ukum Islam dalam Falsafah H ukum Islam (Jakarta: Bumi Aksara, 1992), hlm. 10 
Bustami Saladin

berdasarkan wahyu Allâh swt. dan ijtihâd Rasûlullâh saw. yaitu hukum Islâm dalam perspektif al-Qur'ân dan Sunnah. Masing-masing diyakini oleh umat Islâm adalah syarî'ah, semua tergambar sebagai dalil naqlî atau nash. Hukum Islâm sejauh di-istinbât-kan dari keduanya disebut fiqh nushûsh. Berikut dalam istinbât-nya dengan akal atau pemikiran disebut figh ijtihâdî

Secara etimologis figh berarti pemahaman, pengetahuan yang mendalam, pengertian ini dapat ditemukan dalam firman Allâh swt. dalam surat at-Taubah: 122

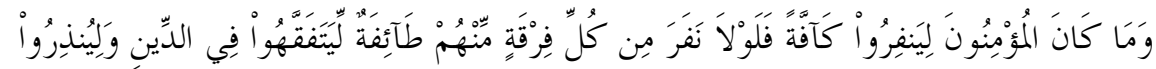

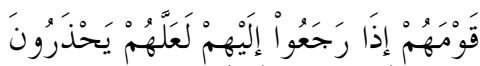

A rtinya: Tidak sepatutnya bagi mukminin itu pergi semuanya (ke medan perang). mengapa tidak pergi dari tiap-tiap golongan di antara mereka beberapa orang untuk memperdalam pengetahuan mereka tentang agama dan untuk memberi peringatan kepada kaumnya apabila mereka telah kembali kepadanya, supaya mereka itu dapat menjaga dirinya. ${ }^{15}$

Pengertian ini sama dengan pengertian dalam $\underline{\text { Hadîts }}$ Rasûlullâh saw:

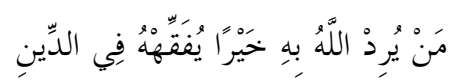

Artinya: A pabila Allâh swt menghendaki kebaikan bagi seseorang maka ia akan memberikan pemahaman agama yang mendalam kepada orang tersebut (H.R.Bukhari dan M uslim).16

Fiqh merupakan syarî'ah yang bersifat amaliyah yang diperoleh dari dalil-dalil secara terperinci. ${ }^{17}$ Sementara itu al-Amidî berpendapat bahwa figh adalah ilmu tentang seperangkat hukum

15 Departemen Agama RI., A I-Q ur'ân .

16 Muhammad Bin Isma'îl bin A bî A bd Allâh al-Bukhârî, Shahîh Bukhârî, (Beirut: Dâr Ibn Katsîr al-Yamâmah, 1978)

${ }^{17}$ Al-Allamah al-Bannânî, H asyiyah al-Bannnânî 'alâ Syarh al-M ahallî ala $M$ atn Jâmi' alJawâmi', Jilid 1 (Beirut: Dâr al-Fikr 1402 H), hlm. 25. Lihat jugă A bd al-Wahhab alKhallâf, 'Ilm U shûl al-Fiqh (Kuwait: Dâr al-Qolam, 1978), hlm. 12 
syara' yang bersifat furu'iyah yang diperoleh melalui penalaran dan istidlâl. 18

Konstruksi yang dapat disimpulkan dari definisi tersebut di atas adalah bahwa figh bukanlah hukum syara' tetapi merupakan interpretasi terhadap hukum syara', karena figh hanya merupakan interpretasi yang bersifat dzannî yang sangat terkait dengan situasi dan kondisi yang sangat melingkupinya. Oleh sebab itu figh senantiasa berubah seiring dengan perubahan ruang dan waktu, hakekat figh yang dapat dipahami sebagaimana definisi tersebut di atas sebagai: (1) figh adalah merupakan ilmu tentang hukum syara'; (2) figh membicarakan hal-hal yang bersifat 'amaliyah furû'iyah; (3) pengetahuan tentang hukum syara' ditetapkan berdasarkan dalil tafshilî yaitu al-Qur'ân dan Hadîts; (4) fiqh digali dan dirumuskan melalui metode penalaran dan istidlâl. 19

\section{Histiografi Fiqh}

Kata figh pada mulanya dipergunakan oleh mayarakat Arab untuk menyebut orang yang ahli dalam mengawinkan unta yang mampu membedakan antara unta betina yang sedang birahi dari unta betina yang sedang bunting. Itulah sebabnya bangsa Arab sangat akrab dengan ungkapan fahlun fâqihun yang merupakan suatu julukan bagi pakar unta. 20

Dari deksripsi tersebut dapat dikembangkan tentang pengertian figh secara umum yaitu pengetahuan dan pemahaman tentang sesuatu. Namun demikian dalam sejarah perkembangan Islâm nampaknya kata figh lebih banyak digunakan untuk memahami agama daripada yang lain. Al-Qur'ân sendiri mempergunakan kata figh dalam konteks pemahaman terhadap masalah-masalah agama, sebagaimana firman Allâh swt. "liyatafaqqahu fi al-dîn" dan sabda Rasûlullâh saw. "yufaqqihu al-dîn", yang menunjukkan bahwa istilah figh tidak dimaksudkan untuk memahami agama dari aspek hukum semata, melainkan untuk memahami agama secara mendalam dari berbagai aspeknya. Kedua

18 Sayf al-Dîn al-A mîdî, al-Ihkâm fî U shûl al-A hkâm, Jilid 1 (Kairo: Mu'assasah alHa alabi, 1967,), hlm. 8

${ }_{19}$ Djamil, Filsafat H ukum Islam, hlm. 9

$20 \mathrm{H}$ asan, TheE arly D evelopment, hlm. 1 
Bustami Saladin

ungkapan tersebut menggambarkan betapa ruang lingkup istilah figh pada masa awal Islâm hingga abad ke-2 $\mathrm{H}$ masih mencakup masalah teologis di samping masalah hukum. ${ }^{21}$

Sebuah buku berjudul al-figh al-akbar yang dinisbatkan kepada Imâm Abû Hanîfah (W 150 H/ 767M) yang hampir separuh isinya berputar masalah dogmatik dan teologi, buku ini ditulis sebagai jawaban atas kepercayaan sekte Qodariyah tentang prinsip-prinsip dasar Islâm seperti akidah, kenabian, dan kehidupan akhirat yang merupakan bahasan dalam teologi. Untuk memberikan gambaran yang komprehensip, dapat disebutkan disini bahwa Imam Abu Hanîfah mendefinisikan figh sebagai ma' rifat an-nafs mâ lahâ wa alayhâ (pengetahuan seseorang tentang hukum dan kewajibankewajibannya). 22

Pengertian figh tidak hanya mencakup masalah teologi akan tetapi pengertian fiqh juga mencakup asketisme yang merupakan sebuah varian dalam tasawuf, karena ada sebuah riwayat yang menguatkan asumsi ini. Suatu ketika ada seorang sufi bernama

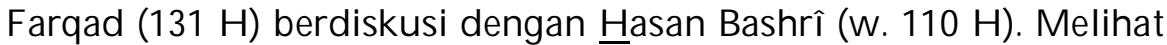
gagasan-gagasan al-Bashrî yang dianggap asing ditengah masyarakat, ia mengatakan bahwa para fuqahâ' akan menentang sikapnya itu. A kan tetapi al-Bashrî menjawab, "Seorang faqih yang sebenarnya adalah seseorang yang memandang hina kepada dunia dan senang kepada kehidupan akhirat, memiliki ilmu yang mendalam terhadap agama, selalu berkata benar dan taat beribadah tidak meremehkan sesama muslim dan memperjuangkan kepentingan umat" .23

Keterangan ini menunjukkan bahwa di samping pemahaman intelektual murni figh juga menunjukkan kepada kedalaman dan intensitas keyakinan, tauhid, hukum peribadatan dan ajaran Islâm lainnya. Pada periode awal perkembangan Islâm juga dijumpai berbagai istilah seperti figh, ilm, imân, tawhid dan hikmah.24 Yang samasama digunakan dalam pengertian umum tetapi kemudian berkembang menjadi lebih khusus dan spesifik.

Setelah berlalunya masa kenabian Muhammad saw., kaum Muslim dihadapkan pada persoalan-persoalan yang baru yang

21 Sahal Mahfudh, Era Baru Fiqh Indonesia (Jogjakarta: Cermin, 1999), hlm. 43

22 Hasan, TheE arly D evelopment, hlm. 3

23 Mun'im A. Sirry Sejarah figh Islam ( Surabaya: Risalah Gusti, 1995 ), hlm. 11-12

24 Al-Ghazâlî, I hyâ' U lûm al-Dîn (Kairo: Dâr al-Fiqr 1993), hlm. 38 
menuntut kepada pengguanaan rasio (exercise of intellegence). Pada saat inilah figh dipahami sebagai hasil penggunaan opini pribadi (opinium prudentium) yang sangat terikat oleh teks. ${ }^{25}$ Pada saat yang sama banyak orang menghimpun dan menulis tradisi-tradisi yang diperoleh melalui cara-cara periwayatan. Jadi pengetahuan yang dihasilkan dari penggunaan kecerdasan dan pendapat pribadi bisa juga di istilahkan dengan figh sedangkan pengetahuan yang diperoleh melalui rangkaian perawi disebut 'ilm.

Berkaiatan dengan hal ini, Fazlurrahman menerangkan bahwa ilmu adalah sesuatu yang sudah diakui secara mantap dan obyektif, sedangkan figh adalah sesuatu yang subyektif karena ia mereflesikan pemikiran pribadi seseorang ulama, sementara ilm adalah suatu proses belajar dan menujukkan kepada data yang obyektif, terorganisir dan terdisiplin, sedangkan figh pada tahap ini adalah nama suatu proses atau kegiatan dalam memahami atau meyimpulkan. 26

Jika disimak hukum Islâm seirama dengan dimensinya dalam sejarah, maka isi pengkajian dalam setiap dimensinya mutlak menampakkan berbagai sistem atau metode. Oleh sebab itu, pada zaman Rasûlullâh saw. hukum Islâm secara bersahaja dapat diperoleh berdasarkan wahyu Allâh SWT dan ijtihâd Rasûlullâh saw, yaitu hukum Islâm dalam perspektif al-Qur'ân dan Sunnah. Masing-masing diyakini oleh umat Islâm adalah syari'at Islâm, semua tergambar sebagai dalil naqli atau nash-nash. Hukum Islâm sejauh di-istinbâtkan dari keduanya disebut figh nushûsh. Berikut dalam istinbât-nya dengan akal atau pemikiran disebut fiqh ijtihâdî

Dalam konteks sejarah Islâm pada tahun $96 \mathrm{H}$ dikenal dengan istilah sanad al-fuqahâ' (tahun fuqaha). Istilah ini muncul karena sejumlah ahli fiqh yang terkemuka di Madinah yakni Sa'îd Ibn Musayyab dan A bû Bakr Ibn al-Rahnmân wafat pada tahun tersebut, oleh karena itu logis kemudian jika diasumsikan bahwa ilmu dan figh terpisah ketika para ahli fiqh dan spesialis $\underline{\text { H}}$ adîts muncul.

Untuk memperkuat argumentasi ini diriwayatkan ketika khalîfah Umar bin abd al-'Azîz (w. 101 H) menginstruksikan kepada A bû Bakr Ibn 브azm (w. 120H) untuk mengkodifikasi 브adîst, Umar

25 Gibb, M uhammadanism, hlm. 102

26 Fazlurrahman, Islam, hlm. 103 
Bustami Saladin

mengatakan ia khawatir akan kemungkinan lenyapnya pengetahuan (durus al-ilm). ${ }^{27}$ Kemudian hadis-hadis ditulis Ibn Shihâb AI-Zuhrî (w. $124 \mathrm{H}$ ) selanjutnya dalam argumentasi lainnya sebagaimana yang dikatakan oleh Ignaz Goldziher bahwa Harun al-Rasyîd telah mengintruksikan kepada gubernur Harmatha untuk melakukan konsultasi.

A khirnya dalam konteks ini dapat dikatakan bahwa 'ilm sejak awal mempunyai pengertian pengetahuan yang diperoleh melalui al-

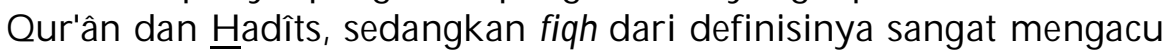
kepada penggunaan rasio dan pemikiran, itulah sebabnya khalîfah Umar bin Khaththâb suatu ketika pernah berkata "Barang siapa yang ingin belajar fiqh ia harus menemui Mu'âdz bin Jabal.28

Mu'âdz yang semasa hidup Rasul pernah pernah diutus menjadi hakim di Yaman dinilai oleh Umar bin Khaththâb telah banyak memiliki pengalaman intellegensia dan hukum yang memungkinkan ia mampu memahami hukum Islâm secara memadai, dan dari analisis diatas dapat ditegaskan kembali bahwa ruang lingkup terminologi figh secara gradual mulai menyempit dan akhirnya diaplikasikan spesifik dalam masalah-maslah hukum dan literatur-literaturnya, demikian juga dengan 'ilm mulai hilang pengertian umumnya dan terbatas kepada Hadîts dan atsar saja, hal tersebut dikarenakan semakin lama persoalan dalam Islâm semakin luas dan kompleks

\section{Seputar Konsep H ukum Islâm}

Setelah Islâm hadir dalam sejarah, aspek hukum sebagai salah satu obyek pengkajian di dalamnya, mempunyai pengalaman sejarah yakni waktu perjalanan sampai kini telah memasuki 5 (lima) periode, yakni; (1) periode Rasûlullâh saw., (2) periode Sahabat Besar atau alkhulafâ' al-râsyidîn, (3) periode Abbâsiyah atau zaman M ujtahid klasik, juga disebut masa kehidupan berpikir atau kemajuan, (4) periode taqlid atau zaman pertengahan, juga disebut masa ketertutupan dan kemunduran, dan (5) periode modern atau zaman pembaharuan.

${ }^{27} \mathrm{H}$ asan, TheE arly D evelopment, hlm. 6

28 Ibn Sa'âd, Thabaqât al-K ubrâ (Beirut: Dâr al-Fikr 1957), hlm. 348 
Para sahabat ketika menerima al-Qur'ân dan Sunnah, mereka tunduk mengamalkannya menurut teks ungkapan semata-mata, kecuali sahabat seperti Umar bin Khaththâb. Tercatat dalam banyak hal ia sering mengusulkan pendapatnya kepada Khalîfah Abû Bakr untuk dijadikan sumber kebijakan, seperti upaya pengumpulan alQur'ân dan sebagainya; begitu pula pendapatnya hingga pendapatnya tersebut akhirnya diputuskan melalui dewan musyawarah sahabat, atau kadang menggunakan kekuasaan otoriternya dalam kapasitas beliau sebagai khalîfah; seperti kebijakannya mencabut hukum potong tangan pada musim krisis pangan, hukum harta rampasan dari hukum perdata hak milik prajurit menjadi milik negara atau membebankan hak bagi khalîfah untuk menarik pajak, sehingga di samping hukum zakat ada hukum pajak, serta reinterpretasi hukum dalam pembagian zakat. Kebijakan dalam contoh di atas dalam konteksnya digali oleh ahli-ahli hukum Islâm modernisme ke dalam kerangka epistimologi baru dalam studi Islâm disebut fiqh siyâsî, di luar studi Islâm disebut politik hukum. Dalam hal tersebut, mungkin para pemikir kontemporer tidak sangat keliru, jika memang terdapat di antara mereka mendukung hak pemerintah untuk men-takhshîsh kaidah umum nash-nash dan membatasi kemutlakannya

Dengan demikian, persepsi para sahabat dalam budaya pemikiran, mereka semuanya menganut paham tekstual terhadap sumber ajaran Islâm. Mereka selain tunduk terhadap suatu kebijakan khalîfah tentang larangan ketat berdiskusi tentang agama kecuali AlQur'ân dan tradisi umum dari Nabi, juga terdapat petunjuk Rasûlullâh saw. memang menolak rasio atau ijtihâd dalam pengembangan dan perluasan ajaran agama. Dalam pada itu, paham Dzahiriah atau tekstualisme, dari zaman klasik sampai sekarang, merupakan bahagian dalam sejarah dan budaya pemikiran hukum Islâm, seirama dan berdampingan dengan paham maknawiyah atau kontekstualisme. Beberapa madzhab klasik dalam bidang hukum, seperti madzhab Dzahirî, Hanbalî dan Ibn Taymiyah serta madzhabmadzhab kontemporer seperti neo-Dzahirî dari Wahhabi di Arab Saudi dan Muhammadiyah di Indonesia; semuanya adalah madzhabmadzhab berasaskan paham lahiriyah atau tekstual, baik budaya pembaharuan yang merujuk kepada al-Qur'ân semata-mata, maupun 
Bustami Saladin

kepada Sunah yang dilegalisir menurut tingkat kualifikasinya, kemudian berikut ditetapkan sebagai mabda' atau sumber hukum.

Hukum Islâm yang terdiri dari dua rangkaian kata "hukum" dan "Islâm" secara tegas tidak terdapat dalam al-Qur'ân walaupun kata hukum baik dalam bentuk ma'rifat maupun nakirah terdapat dalam 24 ayat dalam al-Qur'ân.29 Namun tidak satu pun dari ayatayat tersebut yang merumuskan satu rangkaian kata hukum Islâm. Untuk memahami kata hukum Islâm maka perlu dikemukakan dahulu kata "hukum" dan kemudian kata hukum ini dikaitkan dengan kata "Islâm". Term hukum secara sederhana dapat dirumuskan sebagai seperangkat peraturan tentang tingkal laku manusia yang diakui oleh sekelompok masyarakat disusun oleh orang-orang yang diberi wewenang oleh masyarakat tersebut, berlaku dan mengikat ke seluruh anggotanya, kemudian jika kata hukum berdasarkan definisi tersebut diatas jika dihubungkan dengan kata Islâm maka rumusan hukum Islâm menjadi seperangkat peraturan berdasarkan wahyu Allâh tentang tingkah laku manusia mukallaf yang diakui dan diyakini mengikat untuk semua orang yang beragama Islâm. 30

Hukum Islâm bersifat konstan tidak terpengaruh oleh ruang dan waktu, hanya interprestasi dan pengalaman umat saja yang berubah sesuai dengaan perubahann sosial dan perkembangan zaman, hukum Islâm menerima interpretasi sejauh tidak bertentangan dengan maksud dan tujuan syarî'ah, interpretasi inilah yang kemudian dikenal sebagai fiqh, dengan demikian hukum Islâm mencakup hukum syarî'ah dan figh karena arti syara' terkandung di dalamnya

Adapun tujuan disyariatkannya hukum Islâm adalah merelisasikan dan melindungi kemaslahatan umat manusia, kemaslahatan yang di wujudkan dalam hukum Islâm itu menyangkut seluruh aspek kehidupan manusia yang meliputi tiga aspek yaitu: dharûriyah (prirmer), hajjiyah (sekunder), dan tahsiniyah (komplementer).

29 Fayd Allâh al-ㅂusnî al-Maqdisî , Fath al-Rahnmân (Beirut: Maktabah Ahliyah, 1323 H), hlm. 112

30 A mir Syarifuddin, U shul Figh, Jilid 1, (Jakarta: Logos, 1997), hlm. 5 


\section{Penutup}

Ada tiga macam katagori hukum yang dikenal dalam konsep Islâm, yaitu syarî'ah, figh dan siyâsah. Syarî'ah adalah ketentuan Allâh yang berkaitan dengan mukallaf berupa suatu tuntutan untuk melakukan dan meninggalkan suatu perbuatan, sementara figh adalah pemahaman tentang hukum-hukum syara' yang bersifat perbuatan yang dipahami dari dalil-dalil yang terperinci, sedangkan siyâsah adalah kewenangan pemerintah untuk kebijakan yang membawa kemaslahatan berupa aturan-aturan yang tidak bertentangan dengan agama meskipun tidak ada landasan dalil tertentu. Fiqh sebenarnya upaya manusiawi yang melibatkan proses penalaran (reasoning) baik dalam tataran teoritis maupun praktis dalam memahami dan menjabarkan serta mengelaborasi hukum-hukum agama. Dengan menyebut manusiawi dimaksudkan untuk membedakannya dengan syarî'ah yang secara longgar dipergunakan untuk menyebut agama Islâm dan merujuk kepada hukum Tuhan sebagaimana yang terkandung di dalam wahyu Allâh swt. tanpa melibatkan unsur manusia. Pendeknya figh adalah refleksi dari syarî'ah. Wallâh a'lam bi al-Shawâb.

\section{D aftar Pustaka}

Khallâf, Abd al-Wahhab al-. 'Ilmu U shûl al-Fiqh (Kuwait: Dâr alQolam, 1978.

Hasan, Ahmad. The Early Development of Islâmic Jurisprudence. terjemahan A gah Garnad i. Bandung: Pustaka: 1984.

Bannânî, Al-'Allamah al-. H asyiyah Al-Bannânî 'alâ Syarh al-M ahallî alâ M atn Jâmi' al-Jawâmi'. Beirut: Dâr al-fikr $1402 \mathrm{H}$.

Ghazâlî, al-. Ihyâ' 'U lûm al-Dîn. Kairo: Dâr al-Fiqr 1993.

Syarifuddin, Amir. Pengertian dan Sumber Hukum Islam dalam Falsafah H ukum Islam. Jakarta: Bumi A ksara, 1992.

Syarifuddin, Amir. U shul Figh. Jakarta: Logos, 1997.

Maqdisî, Fayd Allâh al-ㅂusnî al-. Fath al-Rahnmân. Beirut: Maktabah Ahliyah, $1323 \mathrm{H}$.

Djamil, Fathurrahman. Filsafat H ukum Islam. Jakarta: Logos, 1999. 
Bustami Saladin

Fazlurrahman. Islam.. Bandung: Pustaka, 1997.

Gibb, H.A.R. M uhammadan ism. Jakarta: Baratha Karya Aksra, 1983.

Gibb, H.A.R and Krames, J. H. Shorter Encyclopedia of Islam. London: Luzzac, 1961.

Sa'âd, Ibn. al-Thabaqât al-Kubrâ. Beirut: Dâr al-Fikr, 1957.

Schacht, Joseph. A n Introduction in Islamic Law. London: Oxford at the clarendon Press, 1971.

Qaththân, Mannâ al-. al-Tasyrî' wa al-Figh fî al-Islâm. Beirut: Mu'assasah Risâlah, t.th.

Nabhân, Muhammad Farûq. al-M adkhal li al-Tasy'rî' al-Islâmi . Beirut: Dâr al-Shadir, t.th .

Sirry, Mun'im A. Sejarah figh Islam. Surabaya: Risalah Gusti, 1995.

Sahal Mahfudh. N uansa Fiqh Sosial. Jogjakarta: LKIS, 1994.

A mîdî, Sayf al-Dîn al-. al-Ihkâm fî U shûl al-A hkâm. Kairo: Mu'assasah al-Halabi, 1967.

Mahfudh, Sahal. Era Baru Fiqh Indonesia. Jogjakarta: Cermin, 1999. 